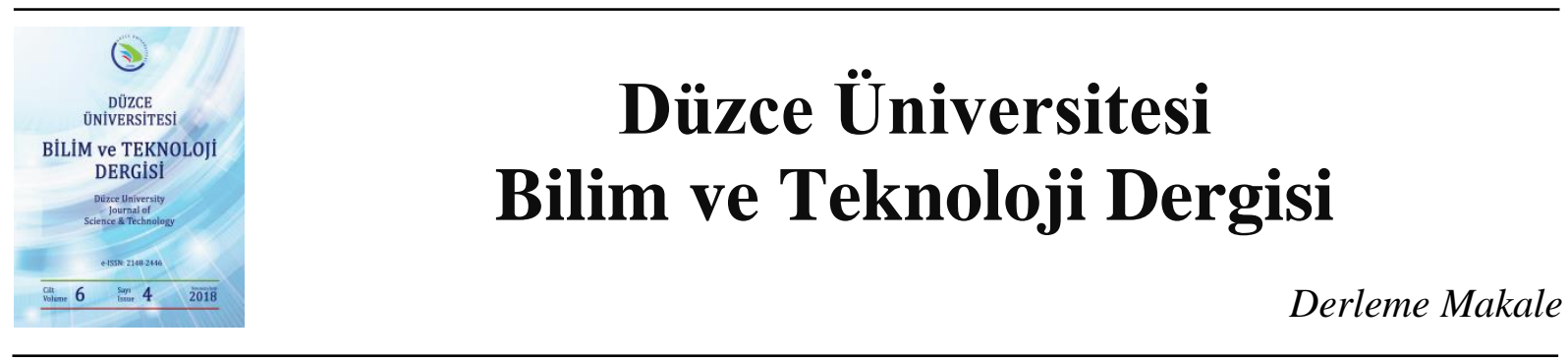

\section{Günümüz Teknolojileri Çerçevesinde Çimento Dünyasındaki Gelişmelerin Araştırılması}

\author{
Nusret BOZKURT ${ }^{\mathrm{a}, *}$, (iD) Nursima SAYIN ${ }^{\mathrm{b}}$ \\ ${ }^{a}$ Inşaat Bölümü, Mühendislik - Mimarlık Fakültesi, Bitlis Eren Üniversitesi, Bitlis, TÜRKIYYE \\ ${ }^{b}$ Inşaat Bölümü, Mühendislik - Mimarlık Fakültesi, Bitlis Eren Üniversitesi, Bitlis, TÜRKIYE \\ * Sorumlu yazarın e-posta adresi: nursimasayin1996@gmail.com
}

DOI: $10.29130 /$ dubited.891254

\begin{abstract}
$\underline{\mathrm{OZZ}}$
Bu çalışmada insanoğlunun her geçen gün artarak ilerleyen hayat standartlarıyla beraber artan altyapı, üstyapı ve konut gibi ihtiyaçlarına cevap veren başlıca yapı malzemesi olan çimento dünyası ve çimento üretimindeki gelişmeler detaylı olarak incelenmiştir. Çimentonun keşfedilmesine kadar geçen süreçte insanoğlu taş, kil ve ağaç parçalarını çeşitli bağlayıcılarla bağlayarak barınma ihtiyacını karşılamaya çalışmıştır. Ardından keşfedilen çimentoyla beraber konutlaşmalarda artış meydana gelmiş ve hem diğer dünya ülkelerinde hem de ülkemizde çimento üretimine başlanmıştır. Çimento üretimi, beraberinde çimento teknolojilerinin gelişmesine olanak sağlamıştır. Ancak artan çimento üretimiyle beraber çevreye verilen zararlar da artmıştır. Bu zararların önlenmesi için de çeşitli teknolojiler geliştirilmiş ve geliştirilmeye de devam edilmektedir. Gelişen teknolojilerin başında atık 1S1 geri kazanım sistemlerinin kurulması, karbon dioksit emisyonunu azaltacak sistemlerin ve alternatif yakıtların kullanılması ve alternatif hammaddelerin çimento ile ikame edilmesi gelmektedir. Bunların yanında yenilenebilir enerji kaynaklarını da kullanarak hem çevreci hem de sürdürülebilir üretim sağlanmaya çalışılmaktadır.
\end{abstract}

Anahtar Kelimeler: Çimento, Çimento Üretimi, Sürdürülebilirlik, Yenilenebilir Enerji.

\section{The Investigation of The Developments in The Cement World on The Frame of Today's Tecnologies \\ ABSTRACT}

In this study, the developments in the cement-world and cement production, which are the main building materials that meet the increasing needs of human beings such as infrastructure, superstructure and housing with increasing life standards, have been examined in detail. During the process until the discovery of cement, human beings tried to meet the need for shelter by connecting stone, clay and wood pieces with various binders. Afterwards, with the discovered cement, an increase in housing has occurred and cement production has started both in other countries of the world and in our country. Cement production has also enabled the development of cement technologies along with it. However, the damage to the environment has also increased with increasing on the cement production. Various technologies have been developed and continue to be developed to prevent these damages. Establishment of waste heat recovery systems, the use of systems and alternative fuels to reduce carbon dioxide emissions, and the replacement of alternative raw materials with cement are among the leading technologies. In addition to these, efforts are made to provide both environmentally friendly and sustainable production by using renewable energy resources.

Keywords: Cement, Cement Production, Sustainability, Renewable Energy.

Geliṣ: 04/03/2021, Düzeltme: 24/04/2021, Kabul: 26/04/2021 


\section{GIRIS}

İnsanoğlunun var oluşundan itibaren günümüze kadar duyduğu en temel ihtiyaçlardan birisi barınma ihtiyacı olmuştur. İlk buzul çağlarında barınma ihtiyacı mağaralarla karşılanırken buzulların erimesiyle insanoğlu mağaradan çıkarak yeni yerler keşfetmeye başlamıştır. Bu da insanoğlunu göçebe hayata yönlendirmiştir [1].

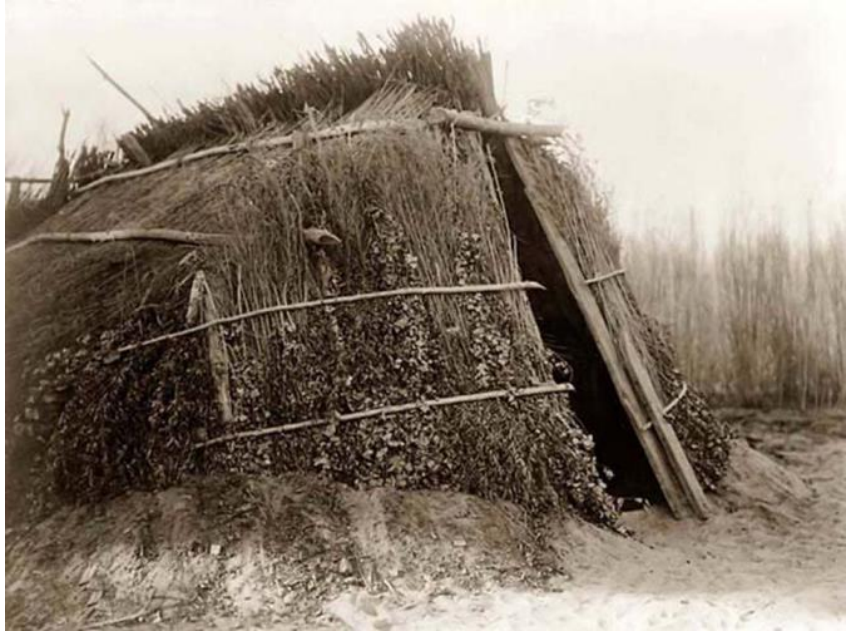

Şekil 1. Ăgaç yaprakları, dallar ve çamurla yapılmış bir barınak [2].

Göçebe hayatta sürekli değişen coğrafyayla beraber iklim koşulları ve yer şekilleri de değişim göstermiştir. Bu da insanoğlunu mevcut koşullarına uygun, yeni ve yaşanılabilir konutlar yapmaya zorlamıştır. Bu yönelim yeni malzemelerin bulunmasına da hız kazandırmıştır. Ormanların bol olduğu yerlerde bağlayıcı ve yalıtım malzemesi olarak çamur kullanılarak dallardan ve odunlardan kulübeler yapılmaya başlanmıştır. Şekil 1'de insanların ağaç yaprakları ve dallarını çamur ile bağlayarak inşa ettikleri ilk barınaklardan biri gösterilmiştir. Ayrıca her coğrafyada da ormanların yoğunluğundan bahsedilememekle birlikte, bu kadar çok yapının inşa edilmesiyle artan ahşap kullanımı ormanların azalmasına sebep olmuştur. Bu yüzden insanoğlu yeniden doğaya yani taşa ve sağlam kayalara yönelmiştir [1]. Sağlam kayaları yontarak ya da taş ve bağlayıcı olarak da çamur kullanarak birçok yapı inşa edilmiştir. Hatta inançlarına göre birçok tapınak inşa etmiş ve tanrılarına görkemli ve ölümsüz eserler armağan etmişlerdir. Şekil 2 ve 3'te gösterilen Mısır piramitleri, Roma ve Yunan tapınakları bu duruma verilebilecek örneklerden sadece birkaçıdır [1,3].

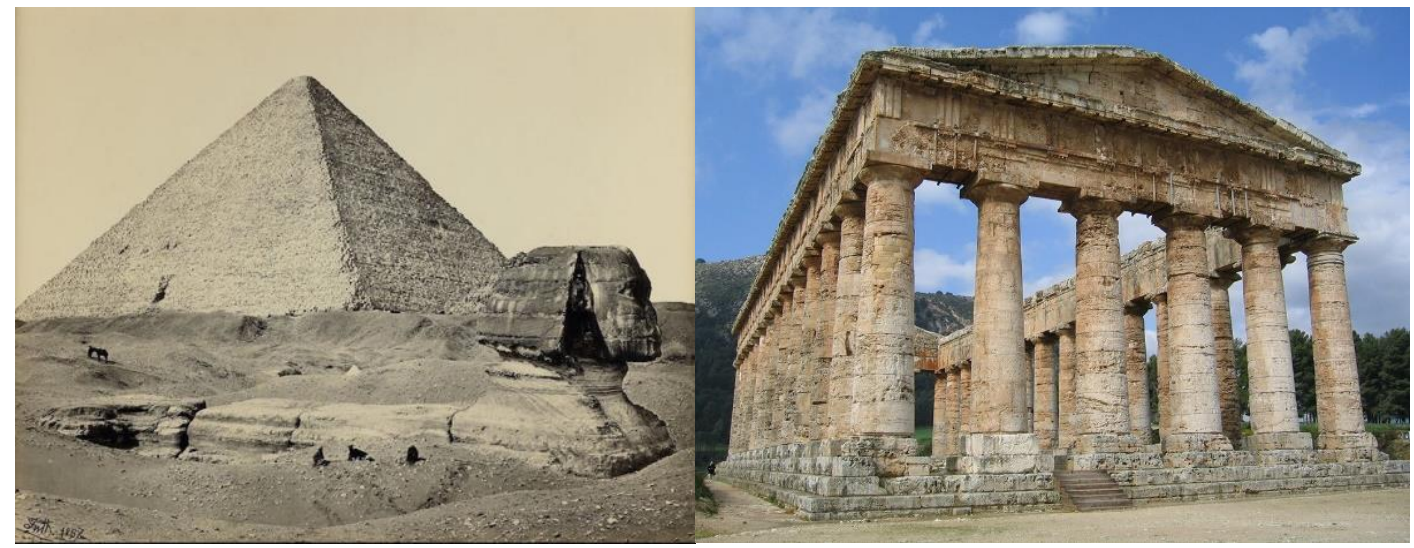

Şekil 2. Misir Piramitleri [4].

Şekil 3. Antik Yunan Tapınağg [5].

Ormanların çok olmadığı coğrafyalarda bazen taş bile bulmak pek mümkün olmayınca daha farklı yapı malzemelerine ihtiyaç duyulmuştur. Suyla birleşince yarı akışkan kıvamda olan ve sertleştiğinde şeklini koruyabilen killi topraklar da yeni birer yapı malzemesi olmuştur [1]. Ayrıca yapılan araştırmalarda killi 
topraklardan inşa edilen yapılarda kille beraber saman saplarının da kullanıldığ 1 görülmüsstür. Saman saplarının kullanımı, daha o zamanlarda bile kilde oluşabilecek çatlakları önlemeye yönelik olduğunu gözler önüne sermektedir. Çatalhöyük'teki evlerin duvarları ve Babil'deki duvar elemanları bu şekilde killi topraklarla inşa edilmiştir [6]. Pişmiş kilin kullanılmaya başlanması ise tamamen bir tesadüf üzeredir ki yine bir doğa olayı sonucunda ortaya çıkmıştır. M.Ö. 3000'li yıllarda Fırat Nehri kıyısında yaşayan insanoğlu bir yıldırım düşmesi sonucu çıkan yangında pişen kilin daha sert ve daha dayanıklı olduğunu görmüştür. Böylece yeni, daha sert ve daha sağlam bir bağlayıcı elde etmek için kil basit fırınlarda pişirilerek kullanılmaya başlanmıştır [1,3]. Bağlayıcı olarak kullanılan kireç ve alçı halihazırda iyi birer malzeme olarak görünse de, suya karşı dirençsiz olmaları hem dayanıklılıklarını düşürmüş hem de kullanım alanlarını da kısıtlamıştır [1]. Bu nedenle sürekli bir arayış içinde olan insanoğlu yeni bir yapı malzemesi aramaya da devam etmiştir. Aynı zamanda kirece, volkanik tüfler, pişmiş tuğla ve kiremit tozları gibi puzolan görevi görebilecek malzemeleri ekleyerek hem suya karşı direncin hem de dayanımın arttırılmasına çalışılmışıtır [6].

İnsanoğlunun arayışları hız kesmeden devam ederken, 1824 yılında bir duvarcı ustası olan Joseph Aspdin tarafından insanlığın barınma ihtiyacının bugününe ve geleceğine yön verecek yeni bir malzeme keşfedilmiştir [6]. Bu duvarcı ustası tamamını doğal killi kalkerden oluşturmak yerine 3 birim kalker 1 birim de kil kullanarak ve bu karışımı yüksek sıcaklıktaki fırınlarda pişirdikten sonra öğüterek dayanım ve dayanıklılı̆̆1 oldukça yüksek gri renkli bir bağlayıcı keşfetmiştir [1]. Yeni keşfedilen bağlayıcının rengi Portland yarımadasındaki doğal killi kalkere benzediği için 'Portland Çimentosu' olarak adlandırılmış ve 21.10.1824 tarihinde 5022 nolu patenti alınmışıtır [3,7]. Aynı zamanda ilk çimento fabrikası da 1848 yılında İngiltere'de kurulmuştur. Ancak İngiltere böylesine büyük bir buluşa ev sahipliği yaparken, Türkiye'nin çimento sektörüne girmesi, Osmanlı'nın çöküş döneminde olmasından ve yeterince su kireci imal edilememesinden dolayı yaklaşık 34 yıl kadar gecikmeli de olsa bir özel sektör girişimiyle 1910 yılında olmuştur [3,8]. Şekil 4'te gösterilen, Darıca'da üretime başlayan ilk çimento fabrikası, tek firınla 20.000 ton/yıl kapasiteyle hizmet vermiştir. 1950'li yıllara kadar çeşitli illerde yeni çimento fabrikaları açılmış, sektörde yer edinmeye çalışan Türkiye, yeterli üretimi sağlayamadığı ve kendi çimento ihtiyacını bile karşılayamadığı için 1970'li yıllara kadar çimento ithalatına devam etmiştir. 1970'lerden sonra kentleşmenin artmasıyla altyapı ve üst yapı çalışmalarında birçok artış meydana gelmiştir. Bu yapılanmayla birlikte artan çimento ihtiyacı, çimento üretiminin artmasına ve sektörde yeni yatırımların yapılmasına da katkı sağlamıştır. Son yıllarda yeni projelerle büyüyen inşaat sektörünün çimento ihtiyacı kendi kaynaklarımızdan sağlanmakta olup, çimento sektörü ihracatta da önemli bir pay edinmiştir. Günümüzde yeniden yapılanmakta olan Libya ve Irak gibi ülkelerle beraber Rusya ve ABD gibi gelişmiş ve gelişmekte olan yaklaşı 90 ülkeye ihracat yapılmaktadır. Bugün ülkemiz mevcut çimento ihtiyacını karşılamakla birlikte, çimento sektöründe dünyanın en büyük ihracatçıları listesinde yer almaktadır [3,9].

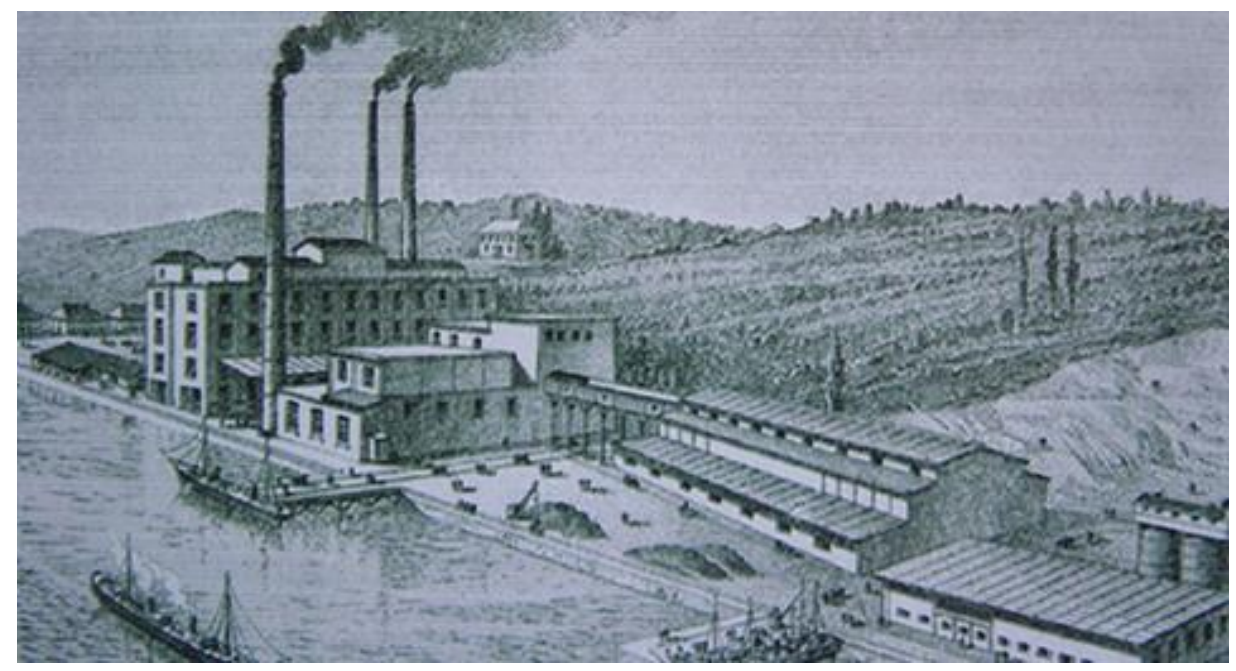

Şekil 4. Türkiye'de açılan ilk çimento fabrikası: Arslan Çimento (Darıca) [10]. 


\section{TÜRKIYE'DE VE DÜNYADA CIMENTO ENDÜSTRİSI}

Çimento, yontulmuş taş kırıntısı anlamındaki Latince "caementum” sözcüğünden türetilmiş ve daha sonra 'bağlayıcı' anlamında kullanılmıștır [6]. Portland Çimentosu, kalker ve kil karışımından oluşan hammaddelerin, yüksek dereceli firınlarda döndürülerek pişirilmesi sonucu oluşan klinkerin, az miktarda alçı taşı ile öğütülmesi sonucu elde edilen hidrolik bir bağlayıcıdır. Hidrolik bağlayıcılar su ile birleştiğinde (hidratasyon) bağlayıcılık özelliği kazanan ve sertleştikten sonra suda erimeyen bağlayıcılardır [11]. Çokça gelişmeye ve değişmeye açık olan çimento sektörü, günümüze gelene kadar birçok gelişme göstermiş olup gelişmeye de devam etmektedir. İlk olarak çimento içerisinde kullanılan puzolanlarda değişim meydana gelmiştir. Puzolanik malzeme olarak yüksek firın cürufu, uçucu kül, silis dumanı kullanılmaya başlanırken, bazı mineraller ve kimyasal katkılar da çimento içerisinde yer almaya başlamışıtır [1].

Çok kompleks bir üretim aşaması olmasa da çimentonun üretim aşamaları çimentonun özellikleri üzerinde oldukça etkilidir. Üretime kalker ve kilden oluşan hammaddenin döner firında pişirilmesiyle başlanır. Çimento üretiminin en önemli aşaması hammaddelerin pişirilme aşamasıdır. Cünkü pişirilme aşamasında hammadde sıcaklığın etkisiyle hem ayrışır hem de ayrışan bileşenler arasında yeni kimyasal olaylar meydana gelir. Bu ayrışma ve reaksiyonlar sonucunda oluşan ana bileşenlerin ve oksitlerin oranları betonun priz alması sırasında, erken ve nihai dayanımında çeşitli karakteristik özellikler göstermesini sağlamaktadır. Yüksek sıcaklıklara kadar ısınabilen bu firına döner firın denmesinin sebebi ise, belirli bir periyotta ve hızda kendi ekseni etrafında dönmesidir. Döner fırına bırakılan hammaddeler, hem kendi içerisinde karışarak hem de 1sınarak, yaklaşık \%3-4 eğime sahip olan firının alt ucuna doğru ilerlemektedir. Fırın alt ucundan $1500^{\circ} \mathrm{C}$ dolaylarında püskürtülen sıcaklık toz kömür, fuel oil ve doğal gaz gibi yakıtların yakılmasıyla sağlanmaktadır. Sürekli hareket halinde olan hammadde ilerleme sağladıkça isınmakta yani pişmektedir. Artık pişmiş olan hammadde firından çıktıktan sonra klinker olarak adlandırılmakta ve bir müddet soğutulmaktadır. Soğutma işleminden sonra klinker bir miktar kalsiyum sülfat ile öğütülerek artık paketlemeye hazır çimento halini almaktadır $[1,11,12]$. Şekil 5'te çimento üretim aşamaları kısaca gösterilmiştir.

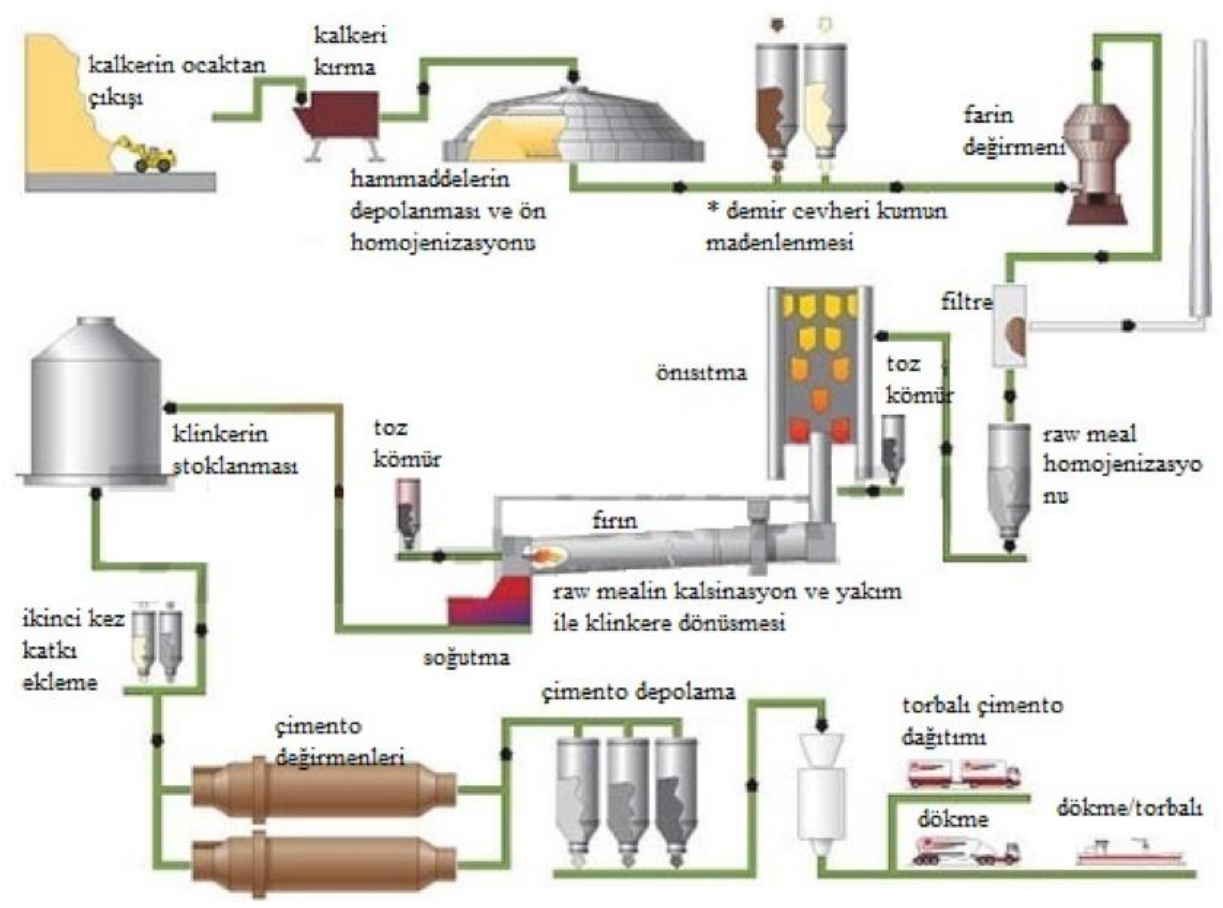

Şekil 5. Çimentonun üretim ve dă̆ıtım aşamaları [13]. 
Gelişmekte olan ülkelerde nüfus artışının görülmesi kaçınılmazdır. Nüfus artışının yanı sıra gün geçtikçe yükselen hayat standartları insanların taleplerinin de artmasına sebep olmaktadır. Artan taleplerin karşılanmasına ilk olarak altyapıyla başlandığı bilinmektedir. Ardından konutlaşma ve sanayileşme, taleplerin karşılanması için ortaya çıkan diğer faktörlerdir. Artan konutlaşmayla birlikte gelişme gösteren ilk sanayi sektörlerinin çimento, beton ve çelik gibi sektörlerin olması kaçınılmazdır. Her ne kadar çimento üretimine geç başlamış bir ülke olsak da, kısa sürede kendi ihtiyaçlarımıza cevap vermekle kalmayıp ihracata başlanmıştır. İlk yıllarda hem fabrika sayısının az olması, hem hammadde eksikliğinden kaynaklı ithalatlar yapılmış olsa da günümüzde ülkemiz çimento ihracatında ilk beşin içerisinde yer almaktadır. Aslında çimento sektörünün sermayesi oldukça yüksek ve enerji tüketimi diğer sektörlere oranla daha fazladır. Ayrıca 200-300 km'den uzak mesafelere taşıma maliyeti oldukça yüksek bulunmaktadır. Tüm bu dezavantajlara rağmen düşük iş gücüne sahip olması ve uzun vadede sermayesinin kat kat fazlasını kazandıran bir sektör olması sebebiyle ülkemizde kısa sürede yaygınlaşan bir sektör olmuştur [14]. Bugün Türkiye Çimento Müstahsilleri Birliği'ne (TMÇB) üye olarak faaliyet gösteren 68 çimento fabrikası vardır [15]. TMÇB'nin 2020 yılı istatistiklerine göre ülkemizde yaklaşık 94 bin ton klinker, 145 bin ton çimento üretim kapasitesi vardır. Klinker kapasitesinin yaklaşık \%83'ü, çimento kapasitesinin ise yaklaşık \%53’ü kullanılmaktadır [16]. Yine TMÇB'nin 2020 yılı istatistiklerine göre ülkemiz 72.299 .054 ton çimento üreterek dünya literatüründe çimento üretiminde ilk sıralardaki yerini korumaktadır [17].

Türkiye çimento sektörüyle dünyada hatırı sayılır bir yer edinse de, dünyadaki gelişmeler de hız kesmeksizin devam etmektedir. Artan nüfusun yanı sıra, gelişmekte olan ülkelerde büyüyen ekonomiler sanayi sektörlerindeki gelişmelerin de önünü açmaktadır. Artan yapılanmayla birlikte çimento sektörü de gelişen ve gelişmeye devam eden sektörler arasında ilk sıralarda yer almaktadır. Çimento tüketiminin artmasıyla birlikte çimento fabrikalarının sayısı da artış göstermektedir. Dünyanın en iyi çimento markalarının başında LafargeHolcim gelmektedir [18]. Yaklaşı 90 ülkede faaliyet gösteren fabrika İsviçre'de bulunmakta, çimento ile birlikte agrega ve hazır beton üretimi de yapmaktadır [18]. Çimento sanayisi üretim, kapasite kullanımı, satış ve pazarlama gibi etmenlere bağlı olduğundan bu fabrikalar gelecek hedeflerine ulaşmak için müşterilerine kaliteli hizmet ve çimento sunmalıdır [19]. Bunun gibi birçok marka bulunmakla beraber [18,19] birçoğu Çin'e ait fabrikalardır. Son yıllarda Çin'de artan çimento tüketimiyle beraber üretim de artış göstermektedir. Şekil 6 sunulan grafikte de görüldüğü üzere son yıllarda çimento üretiminde diğer birçok ülkeyi açık ara geride bırakarak dünyada üretilen çimentonun yarısını üreten Çin ilk sırada yer almaktadır [20]. Oldukça artan güçlü konut talebiyle 2020 yılında Çin'de çimento üretiminde yaklaşık \%1-2 artış olması beklenmektedir [21,22]. Çin'in hemen arkasından gelen Hindistan'da, çimento tüketimi ekonomik nedenler ve azalan altyapı yatırımlarıyla keskin bir şekilde düşüş sergilese de, 2020 yılında \%4-5'lik bir artış göstermesi beklenmektedir [21,22]. Cement 2020 Raporu'ndaki verilere göre 2020 y1lında Orta Doğu hariç tüm dünyada çimento talebinde artış beklenmektedir [21]. Global Data'ya göre Türkiye hükümeti ekonomik büyümeyi 2023 yılına kadar arttırmayı hedefleyerek ulaşım, altyapı ve konut gibi birçok alanda çimento talebinin ve dolayısıyla üretiminin artması beklenmektedir [21,22]. 


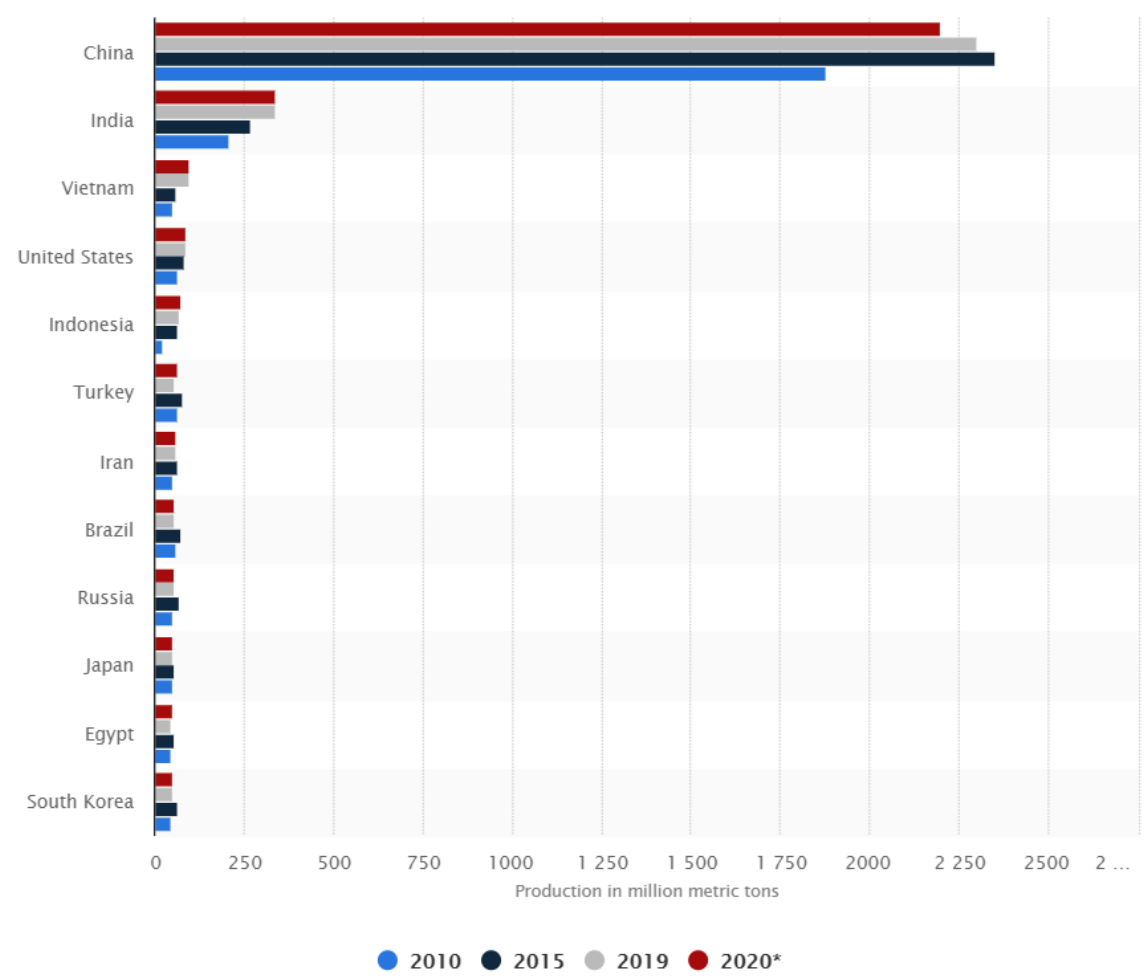

Şekil 6. 2010-2020 yılları arasında çimento üretiminde dünya ülkeleri grafiği [20].

Son yıllarda neredeyse tüm sanayi sektörlerinin gündemine oturan Endüstri 4.0 hedefi, 4. sanayi devrimi sayılabilecek yeni bir oluşumdur. Şekil 7'de de görüldügü üzere ilk sanayi devrimi mekanik üretim tesisleriyle başlamıştır. Ardından elektrik ve iş bölümünün devreye girdiği ikinci sanayi devrimi gerçekleştirilmiştir. Gelişen elektronik ve bilgi teknolojilerinin kullanılmasıyla üçüncü sanayi devrimi 'dijital devrim' olarak ortaya çıkmıştır. Dijitalleşmenin getirdiği taleplerle birlikte internet altyapısıyla sağlanan yüksek hızlı bağlanabilirlik, tüketicilerinin gereksinimlerini değiştirerek üreticileri yeni teknolojileri en iyi şekilde kullanmaya sevk etmiş̧ir. Endüstri 4.0 teknolojisiyle birlikte bilişim teknolojileri ve endüstrinin birleşmesi sağlanmıştır. Bu sayede makineler birbirleri ile iletişime geçerek veri analizi yapabilecek ve insan kaynaklı hatalar en aza indirilmiş olacaktır. Ayrıca sistem daha az maliyetle çalışacak ve daha çabuk üretim yapılarak zamandan tasarruf edilmiş olacaktır. Bu sebeplerle günümüzde Endüstri 4.0 ile birlikte endüstrinin her alanında sistemlerin daha küçük ancak daha güvenilir olacağ 1 beklenen bir gerçektir [23,24]. Bu gelişmelerle beraber çimento sektörü de her geçen gün artarak devam eden teknolojilere uyum sağlayarak, etkin kaynak kullanımını ve verimliliğin artmasını amaçlayan Çimento 4.0 dönüşümünü gerçekleştirecektir.

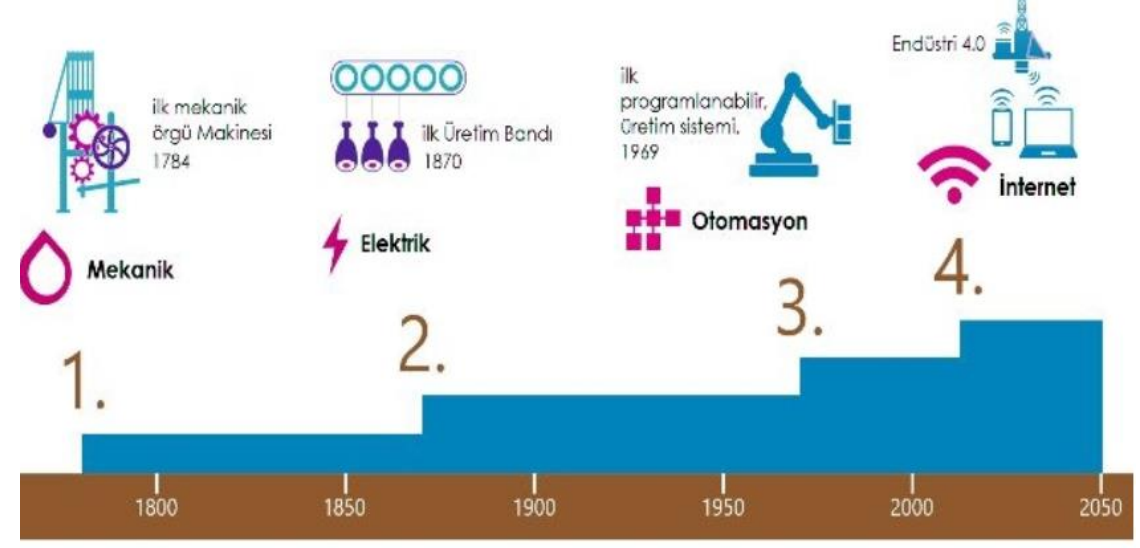

Şekil 7. Endüstri 4.0'a kadar gelişen sanayi devriminin evreleri [23]. 


\section{CIMMENTO SEKTÖRÜNDE SÜRDÜRÜLEBILİRLİK, YENILENEBILIR ENERJI KAYNAKLARI VE GERI DÖNÜSÜM ÜRÜNLERI}

İlk çimento fabrikasının kurulduğu günden bugüne kadar süregelen çimento sektörü, insanoğlunun en önemli ihtiyaçlarına cevap verirken, öte yandan da oluşturduğu atıklar, harcanılan enerji, yüksek oranda havaya salınan karbon dioksit gazı gibi sebeplerle, insanoğlunun her zaman muhtaç olduğu ve olacağı doğaya ve çevreye de birçok zararlar vermektedir. Verdiği zararları görmezden gelebilsek bile sarf edilen enerjinin çokluğu göze çarpan önemli bir detay olmaktadır. Çimento üretimi esnasında fabrikalarında kullanılan elektrikten, döner firında kullanılan yakıtlara kadar enerji sarf edilen birçok aşaması mevcuttur. Yukarıdaki bölümlerde verilen bilgiler ışığında çimento üretiminin yıldan yıla artış gösteriyor olması hayatımızda beton kullanım oranının gün geçtikçe artmış olduğunu göstermektedir. Beton, çimento esaslı inşaat malzemelerinin en çok talep görenidir [25]. 2017 yılı verilerine göre dünyada yaklaşık 10 milyar metreküp hazır beton üretilmiştir. Bu da dünyada kişi başına düşen beton miktarının yaklaşık 1.5 metre küp (yani 3.5 ton) olduğunu gözler önüne sermektedir. Bu istatistikler dünyada betonun sudan sonra en çok tüketilen malzeme olduğunu ispatlar niteliktedir. Beton üretmek için kullanılan genel malzemeler çimento, su ve agregadır. İyi bir beton üretmek için gereken agrega oranı \%70-80 arasında olmalıdır. Yani 10 milyar metreküp hazır beton üretmek için gereken agrega miktarı, ortalama yüzde \%72 agrega eklendiğini varsayılarak 7.2 milyar metre küp olarak hesaplanabilir. Çimento, betonun yaklaşık \%10'unu oluşturmaktadır. 10 milyar metre küp hazır beton üretimi için 1 milyar metre küp (yaklaşık 3 milyar ton) çimento kullanılır. Eklenmesi gereken su miktarı ise 1.8 milyar metre küptür $[26,27]$. İstatistiklere bakıldığında giderek artan hazır beton üretimiyle beraber artan çimento üretimi ve su tüketimindeki artış da göze çarpmaktadır.

Son yıllarda giderek gündeme oturan su ayak izi, bir malın ya da hizmetin ortaya konması için harcanan toplam tatlı su miktarı olarak ifade edilmektedir [28]. İnşaat sektöründe ise su ayak izi birçok kalemde karşımıza çıkmaktadır. Tablo 1'deki verilere bakıldığında $1 \mathrm{~m}^{3}$ beton üretmek için gereken çimento, agrega ve kimyasal katkıların üretimi için gereken toplam su miktarı yaklaşık 250 litredir [29]. Giderek artmakta olan hazır beton üretimiyle birlikte beton ve çimentonun su ayak izi her geçen gün artmaktadır. Aslında su ayak izi demek, ihtiyacımız olan tatlı su kaynakları demektir. Bu nedenle her sektörde olduğu gibi çimento sektöründe de su ayak izini azaltabilmek için çalışmalar yürütülmektedir. Atık suların geri dönüşümü sağlanarak yeniden beton üretiminde kullanılmasına ilişkin çalışmalar mevcuttur [30]. Su, beton üretiminde hem karışım suyu hem de kür suyu olarak tüketilir. Ancak atık suların yeniden beton üretiminde kullanılabilmesi için zararlı kimyasallardan arındırılması zorunludur [30]. Çünkü içerisindeki zararlı kimyasallar, çimento hamurunda istenmeyen reaksiyonlar gösterebilir ve bu durum beton dayanımını istenmeyecek şekilde değiştirebilir.

Görüldüğü gibi çimento ve beton üretiminde su kullanımı oldukça yüksektir. Artan küresel ısınma ve tükenmekte olan su kaynakları da göz önüne alındığında, suyun verimli kullanılması da yapılması gereken en önemli yatırımlardan olmaktadır. Ayrıca tüketilen suyun çokluğu bir kenara bırakılsa bile, hızla artan betonarme yapılar, beraberinde artan beton ve çimento üretimini getirmektedir. $\mathrm{Bu}$ da çevreye zarar vermekle beraber, insanları yaşam alanlarının betonarmeden ibaret olacağı bir geleceğe sürüklemektedir. 
Tablo 1: $1 \mathrm{~m}^{3}$ hazır beton üretiminde kullanılan malzemelerin üretimi için gereken su miktarları [29].

\begin{tabular}{ccc}
\hline Bileşen & Miktar $\left(\mathbf{K g} / \mathbf{m}^{\mathbf{3}}\right)$ & Su İçeriği (Litre/Ton) \\
\hline Çimento & 290 & 1000 \\
\hline Agrega & 1900 & 1000 \\
\hline Su & 175 & 1000 \\
\hline Kim. Katkı & 4,5 & 650 \\
\hline Toplam & 2369,5 & 3650 \\
\hline
\end{tabular}

Sürdürülebilirlik anlam olarak üretkenliğin devamlılı̆̆ını sağlayarak daimi olma yeteneğini koruma anlamına gelmektedir [31]. İlk olarak 1987 yılında Birleşmiş Milletler Çevre Kalkınma Komisyonu'nun hazırladığı bir raporda değinilmiş bir madde olarak yaşantımıza girmiştir. Bu madde ile insanoğlu günlük ihtiyaçlarını karşılarken, hem gelecek nesillerin ihtiyaçlarını ihmal etmeyerek hem de "kalkınmayı sürdürülebilir hale getirebilir" denilerek, sürdürülebilirlik kavramı, birçok sektörde karşımıza çıkmak üzere hayatımızda önemli bir yer edinmiştir [32]. Sürdürülebilirliğin ilk olgusu elbette ki dengedir. Çünkü insanlık ihtiyaçlarını temin ederken, mevcut kaynakları tamamen tüketmeden gelecek nesillere aktarımı da göz önüne almalıdır, bu da ancak denge ile olur. Dengeli tüketim ve üretim mantığıyla kullanılan kaynakların tüm ihtiyaçlara tam anlamıyla cevap vermesi sağlanmış olmakla beraber geleceğe aktarımı da sağlanmış olur. Sürdürülebilirliğin bir diğer olgusu da doğal yaşamdır. Tüketim ve üretim doğrultusunda meydana gelecek her türlü olay, çevremizi de etkilemektedir. Yani insanoğlu sektörlerde sürdürülebilirliği sağlarken çevreye duyarlılığını da arttırmakla yükümlüdür. Çünkü gelecek nesillere aktarılacak en önemli şey tartışmasız daha yaşanılabilir bir çevredir. $\mathrm{Bu}$ kapsamda günümüzdeki hemen her sektörde sürdürülebilirlik sağlamak adına birçok çalışma yürütülmektedir. Yine çimento sektörü de sürdürülebilirliği sağlamak adına çeşitli çalışmalar yapmaktadır. Sürdürülebilirlik kavramı, çimento sektörünce ele alındığında, çevreci üretim, üretim sırasında kullanılan kaynakların ve oluşan atıkların çevre üzerindeki etkisi, maliyet-kâr oranı, risk oranı, rekabet, etik ve yönetim gibi birçok başlıkta karşımıza çıkmaktadır. Çimento, kaynaklarını doğadan alan bir sektör olduğu için yapılan yatırımlar genellikle çevreyi koruma temelli olmaktadır. Bunun için sektörde yapılan çevreci ve sürdürülebilirliği sağlama çalışmalarının başında doğaya salınan zararlı gazların azaltılması gelmektedir. Salınımı azaltmak adına alternatif hammadde ve alternatif enerji kaynağı araştırmaları her geçen gün artarak devam etmektedir. Bununla birlikte enerjinin verimli kullanılması ve çeşitli geri kazanım sistemleriyle kullanılamayan enerjinin yeniden kullanıma katılmasını sağlamaya çalışmak da önemli çalışmalardan biridir.

Aslında çimento üretimi yapılırken amaç minimum enerji ve minimum çevre zararıyla maksimum verim, tasarruf ve sürdürülebilirlik elde etmek olmalıdır. İșin bu kısmı çok ütopik görünse de bu üretim çok da uzak bir gelecekte değildir. Gerek fabrikaların gelişme ve geliştirme çabaları olsun gerek akademik ve bilimsel çalışmalar olsun, çimento sektörünü her geçen gün daha ileriye taşımayı hedeflemektedir. Hemen hemen her sektörde olduğu gibi çimento sektöründe de ileriyi hedeflemek için mevcut ihtiyaçları optimum şartlarda ve yüksek verimde karşılarken, öte yandan da en önemli parçamız olan doğaya verilen zararı en düşük seviyeye çekmek gerekmektedir. Bunun için çeşitli çalışmalar yapılmaktadır. Örneğin çimento fabrikalarında en çok elektrik tüketen 'proses fanlarının' verimliliğini arttırarak hem elektrik kullanımını düşürmek hem de doğaya salınan karbon dioksit oranını azaltmak için çeşitli çalışmalar yürütülmektedir $[33,34]$. Bazı çimento fabrikalarında ise alternatif yakıt ve hammadde kullanımıyla enerji tasarrufu sağlanıp bununla birlikte sürdürülebilir verimlilik sağlanmaya çalışılmaktadır [35]. Elbette bu tasarrufla birlikte doğaya salınan karbon dioksit oranının ciddi oranda azalması ise çevreci çimento üretimine katkı sağlamaktadır. 


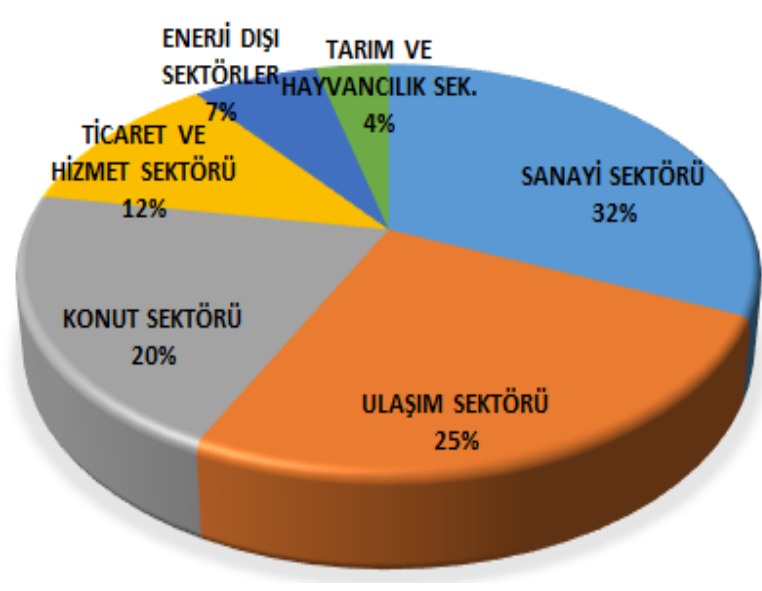

a)

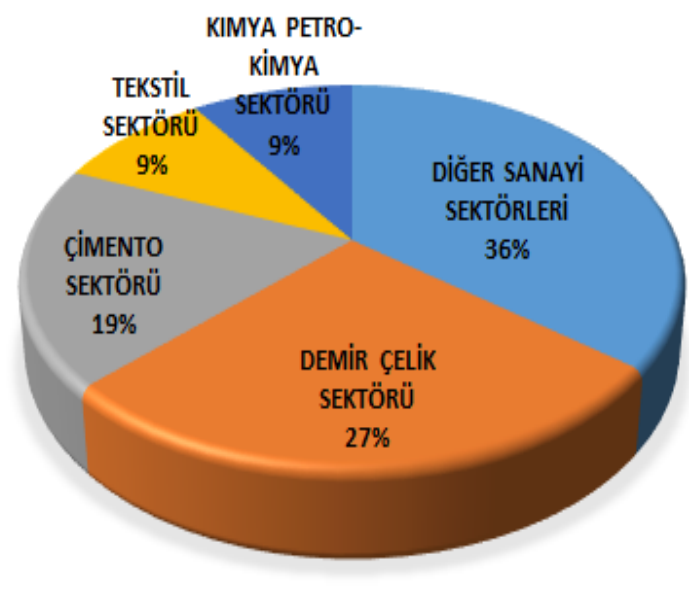

b)

Şekil 8. (a) 2017 yılı sektörel enerji tüketimi (BINN TEP) grafiği, (b) 2017 yılı sanayi alt dallarının toplam sanayi enerji tüketimindeki dă̆llımları (\%) grafiği [36].

Şekil 8'deki grafiklerde de görüldüğü üzere sanayi sektörü, elektrik tüketimi konusunda sektörler arasında ilk sırada yer almaktadır. Sanayi sektöründe ise en çok elektrik tüketen sektörler sıralamasında çimento sektörü ikinci sırada yer almaktadır. Çimento üretiminde tüketilen elektrik enerjisi miktarı, bu sektörde kullanılan enerjinin yaklaşık \%10-15'ini oluşturmaktadır. Aslında çok küçük bir yüzde gibi görünse de, maliyet açısından oldukça büyük bir oran oluşturmaktadır [34]. Bu da sektörde enerji tasarrufu ve sürdürülebilirlik sağlamak için yeni çalışmaların yapılmasına olanak sağlamaktadır. $\mathrm{Bu}$ çalışmalardan biri de atık 1sı geri kazanımıdır. Çimento sektörü ve diğer üretim aşamalarında isı kullanımı gerektiren sektörlerde, genellikle 1sının tamamı kullanılamamakta ve kullanılamayan kısım farklı yollarla ya da gaz bacalarıyla doğaya salınmaktadır. Ancak bu durum, çevreye verdiği zararın yanı sıra ciddi ölçüde bir enerji kaybına sebep olmaktadır. Atık 1sı geri kazanımı (Waste Heat Recovery) tesisleriyle, kullanılamayan ve doğaya salınan ısının, yeniden bir üretim döngüsüne sokulması sağlanmakta ve bu döngü sonucunda elektrik üretimi gerçekleştirilmektedir. Bu döngünün başlica aşamaları atık ısının buhar kazanlarına enerji olarak girmesini sağlamak ve üretilen buharı türbinlere yollamaktır. Buhar enerjisiyle dönen türbinlerde üretilen enerji jeneratörlere aktarılarak, elektrik üretimi gerçekleştirilir $[36,37]$.

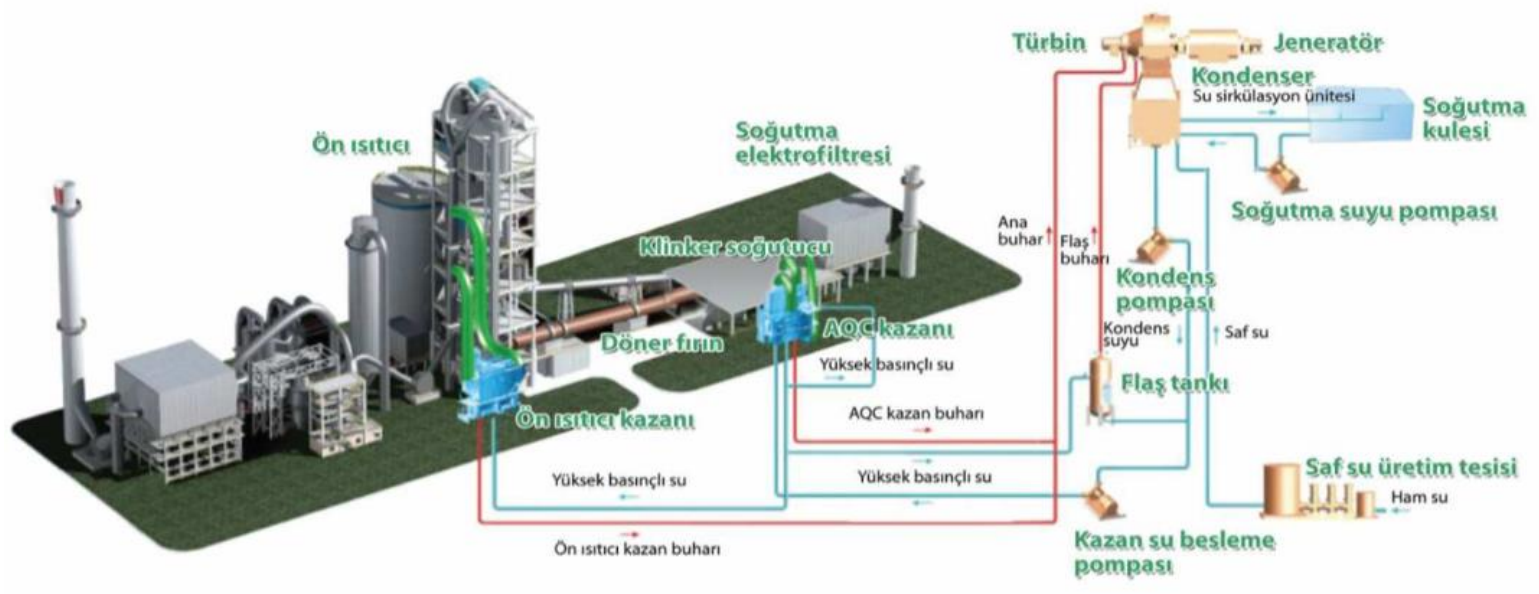

Şekil 9. Atık Isı Geri kazanım Akış Şeması [37]. 
Şekil 9'da üretim aşamaları gösterilen atık 1S1 geri kazanımı tesisleriyle çimento üretim aşamasında kullanılan elektriğin \%25'i üretilebilmektedir. Aynı zamanda bu üretim sırasında yakıt kullanılmaması kaynak tasarrufu sağlarken, yakıt kullanımından kaynaklı sera gazlarının salınımı da engellenmektedir. $\mathrm{Bu}$ üretimle hem tasarruf hem de sürdürülebilirlik sağlanmaktadır. Artan güç ve yakıt maliyetleri, karbon dioksit emisyonunun azalması ve sürdürülebilirliği sağlama çabaları son yıllarda birçok şirketin gündemini oluşturmaktadır [34]. Bu yüzden atık ısı geri kazanım sistemleri oldukça ilgi görmektedir. Sistemin güvenli olması da yaygınlaşmasına katkı sağlamaktadır [34]. Atık ısı geri kazanım tesislerinin ülkemizdeki fabrikalarda kullanımına 2019 yılı temmuz ayı itibariyle devreye alınan 14 fabrika ve 23 hatta devam edilmektedir. Bu yatırımların arttırılması için çeşitli teşvik, destekleme ve yatırım çalışmaları sektörle alakalı çeşitli birlikler tarafından yapılmaktadır [36]. Bunların yanı sıra çimento sektöründe atık malzemelerin ve yeni teknolojilerin kullanımları ile ilgili birçok akademik çalışma da mevcuttur [38-41]. Birçok çalışma çimentonun ikamelerinin özelliklerinin incelemesi üzerine iken, yine birçoğu ise alternatif hammadde ve yakıt arayışına yöneliktir. Yani bütün çalışmaların ortak paydası çevreci çimento üretimi ve sürdürülebilirliktir.

Çimento üretiminde sürdürülebilirliğin ötesinde yenilenebilir enerji kaynaklarının da etkilerini görmek mümkündür. Aslında sürdürülebilirlik ve yenilenebilir enerji kaynakları birbirine çok uzak başlıklar da değildir. Çünkü sürdürülebilirliği sağlamak için sürdürülebilen üretime yani kaynaklara dolayısıyla yenilenebilir kaynaklara ihtiyaç vardır. Yenilenebilir enerji kaynaklarının kullanılması son yıllarda birçok farklı sektörde yaygınlaşmaya başlamıştır. Sanayi sektörlerinde hızla yaygınlaşan yenilenebilir enerji kaynaklarının kullanılması, hem tasarruf açısından hem de çevreye verilen zararların azaltılması açısından oldukça büyük bir öneme sahiptir. Bazı sektörlerde kullanılmaya başlanan rüzgar türbinleri ya da güneş enerjileriyle elektrik enerjisinden ciddi miktarlarda tasarruf sağlanması amaçlanmaktadır [42-45]. Hâlihazırdaki bazı çimento fabrikaları da güneş ve rüzgar türbinleri kullanıp kendi elektrik enerjilerini üreterek, hem enerji yatırımlarından tasarruf sağlamış olup hem de çeşitli sera gazlarının salınımının azaltılmasında önemli rol oynamaktadır [46-49]. Sanayi sektörlerinde alternatif enerji kaynaklarının kullanıma başlanmasıyla beraber, TÜİK verilerine göre 1970'li yıllarda yaklaşı \%70 oranlarında tüketilen elektrik enerjisi, 2017 yılında \%46,8'lere kadar düşmüştür [50].

Çimento sektöründe kullanılan yakıtlardan oluşan gazın çevreye salınmasından birçok canlı zarar görmekte ve küresel ısınmaya da negatif yönde katkı sağlamaktadır. Bu durumdan en çok zararlı çıkacak olan elbette ki başta insanlar olmak üzere tüm canlılardır [51]. Zararlı gazların başında karbon dioksit gelmektedir. Karbon dioksit bitkiler gibi bazı canlıların vazgeçilmezi iken insanlar ve hayvanlar gibi canlıların ise hem nefesini kirleterek hem de küresel 1sınmaya katkı sağlayarak çözülmesi gereken başlıca sorunlardan biri olmaktadır [52]. Karbon dioksit emisyonunu azaltmak için birçok çalışma yapılmaktadır [34,52-54,]. Atık 1s1 geri kazanım sistemleri, alternatif hammadde ve yakıtlar bunların başında gelmektedir. Çimento üretiminde kömür, linyit, fuel oil, petrokok gibi fosil yakıtlar kullanılmaktadır [32,55]. Bu yakıtlar maliyet açısından üreticiye yük teşkil etmekle beraber, çevreye verdiği zararlar da azımsanmayacak kadar büyüktür. Çimento üretimindeki yakıt kullanımı, tüketilen toplam enerjinin yaklaşık \%35-45'ini oluşturmaktadır [55]. Çimento sektöründe alternatif yakıt arayışları sonucunda kullanılmakta olan bazı alternatif yakıtlar şunlardır: ömrünü tamamlamış lastikler, atık yağlar, endüstriyel plastikler, atık kâğıtlar, arıtma çamuru, tekstil atıkları ve bitki kabukları [25,32,55]. Kullanılan bu alternatif yakıtlar sayesinde havaya salınan karbon dioksit salınımının azaltılması sağlanmış olmaktadır. Aynı zamanda kaynak kullanımını azalttığı için sürdürülebilirliğe de katkı sağlamaktadır [32,55]. Alternatif yakıtların kullanılmasıyla gereken enerjinin yaklaşık \%30'u karşılanmış olmaktadır. $\mathrm{Bu}$ da maliyet açısından ciddi tasarruflar sağlar ve atıklar yeniden değerlendirilerek üretime katılmış olur [55]. Birçok ülkede hâlihazırda uygulanan alternatif yakıt teknolojisi bazı ülkelerde \%70 ikame oranlarına ulaşmaktadır [25]. 
Son y1llarda geri dönüşüm ürünlerinin de çimento sektöründe kullanılmasına yönelik çalışmalar yapılmaktadır. Geri dönüşüm sonucunda yeniden değerlendirilme imkânı olan atık ürünlerin çeşitli kimyasal işlemlerden geçirilerek yeniden kullanıma kazandırılması sağlanmaktadır [8]. Kâğıt, cam, demir, çelik, bakır, plastik ve ömrünü tamamlamış lastikler gibi birçok madde geri dönüşüme katılabilmektedir. İnşaat sektöründe kullanılan geri dönüşüm ürünlerinin başında, inşaat yıkıntılarından çıkan beton yığınlarının içerisindeki donatıdan ayrılarak ve ilgili makinalarla küçük parçalara ayrılarak yeni üretilecek beton içerisinde agrega olarak kullanılması gelmektedir. Ayrıca ahşap, tuğla, cam, asfalt ve yalıtım malzemeleri gibi inşaat ürünlerinin de geri dönüşümü sağlanarak hem inşaat sektöründe hem de diğer birçok alanda yeniden kullanıma kazandırılması sağlanmaktadır [56]. Çimento sektörünün temelinde doğal kaynakların bulunması, özünde pahalı bir üretimin olduğunu göstermektedir. Ancak geri dönüşüm yoluyla kullanılabilecek ürünler, yeni kaynak üretiminden tasarruf sağlayarak ekonomik olarak ciddi tasarruflar sağlamaktadır. Ayrıca doğaya yani insana verilen zararlar minimize edilmeye çalışılıp, sürdürülebilirliğe katkı sağlanmaktadır. Örneğin pulverize kömür, çimento üreticilerini yeni kaynak maliyetinden kurtaracak önemli malzemelerden biridir. Termik santrallerde pulverize kömürün yakılmasıyla baca fitrelerinde atık olarak biriken kül, uçucu kül olarak adlandırılır ve çimento ikamesi olarak kullanılmaktadır [57]. Bu sayede hem hava kirliliğinin önüne geçilmiş olup hem de kaynak maliyetinden tasarruf sağlanmaktadır. Bununla birlikte pirinç kabuğu külü, testere tozu külü, hurma yağı yakıt külü, hindistan cevizi kabuğu gibi çeşitli tarımsal atıklar agrega ya da çimento ikamesi olarak kullanılmaya başlanmıştır [51]. Bunların geri dönüşüme kazandırılarak yeniden işlenebilmesi hem atıkların bertaraf edilmesi için gereken maliyeti düşürür hem de atıkların depolandığı alanlardan tasarruf edilmektedir. Ancak en önemli avantajı ise çevre kirliliğinin önüne geçerek yeşil (çevreci) üretime katk1 sağlamaktır [51].

\section{IV.SONUC}

İnsanoğlu, varoluşundan itibaren öncelikle karnını doyurmuş ardından yaşayabilmek için kendini güvende tutabileceği yerler aramıştır. İlk çağlardan bugüne gelene kadar sürekli değişen iklim koşulları ve göçebe hayatla değişen yerleşim yerleri, insanları hep yeni şartlara uygun, güvenli yapılar inşa etmeye itmiştir. Kaya parçaları, taşlar, ağaç dalları ve yapraklar kullanılmaya çalışılırken bağlayıcı görevini çamur ve killi topraklar üstlenmiştir. Daha sonra bir duvarcı ustasının buluşuyla hayatımıza giren çimento, sadece bir bağlayıcı malzeme olarak kalmayıp hem bulunduğu çağa, hem günümüze hem de uzak geleceğe hızla yön vermektedir. Her ne kadar ülkemiz çimento üretimine geç başlamış olsa da, çimento piyasasındaki yerini çabuk edinmiştir. Günümüzde kendi ihtiyaçlarını karşılamakla kalmayan Türkiye, dünyaya çimento ihraç etmektedir.

Çimentonun çok karmaşık bir üretim aşaması olmasa da üretim basamaklarında meydana gelen reaksiyonlar betonun dayanım özellikleri üzerinde oldukça etkilidir. Ayrıca enerji temelli bir üretimi olduğundan enerji tasarrufu sağlamak adına birçok çalışma yapılmaktadır. Ulaşım, alt yapı, üst yapı, konut gibi birçok alanda insanlığa hizmet eden çimento, birçok ülkede artarak üretime devam etmekte ve oldukça fazla tüketilmektedir. Küresel ekonomide pazar payı oldukça yüksek olan çimento sektöründe Türkiye, dünya literatüründe hem üretimde hem de ihracatta oldukça iyi bir yer edinmiştir. Son yıllarda duraklama yaşadığı görülen çimento sektörünün ilerleyen y1llarda yeniden canlanacağ beklenmektedir. Ayrıca hemen her sanayi sektöründe karşımıza çıkan endüstri 4.0 çağı, çimento sanayiinde de kullanılmaya başlanacak ve hem hızlı hem de sürdürülebilir üretim sağlanmaya çalışılacaktır.

Halihazırda sudan sonra en çok tüketilen malzeme olan beton ve dolayısıyla çimento, kullanılmaya başlandığı günden itibaren çevreye dostça yaklaşabilen bir malzeme olmamıştır. Gerek üretiminde 
kullanılan su ve diğer kaynakların tüketimi olsun gerek oluşturduğu atıkların çevreye verdiği zararlar olsun çimentonun dezavantajlarını, avantajlarının arkasına saklayamamıştır. Elbette ki çevre dostu çimento üretmek artık günümüz teknolojileri ile mümkündür. Yeşil binaların imarının artmasıyla birlikte yeşil üretimler de hız kazanmıştır. Çimento fabrikalarına yapılan yatırımlar, kurulan geri kazanım sistemleri, alternatif yakıt ve kaynaklar, yenilenebilir enerji kaynakları, geri dönüşüm ürünleri ve dahası yeşil ve sürdürülebilir üretimin adımlarıdır.

Çimento, yeni yüzyılda hayatımızın vazgeçilmez bir parçası haline gelmiş̧ir. Ancak görünen odur ki yakın gelecekte artan çimento üretimi ve tüketimiyle beraber, betonarmeden ibaret olan bir dünyada yaşamak zorunda olunacaktır.

\section{KAYNAKLAR}

[1] A. Yeğinobalı, Çimento 'Yeni Bir Çağın Malzemesi', Türkiye: Demo Reklamcılık ve Bilişim Hizmetleri Ltd. Şti., 2003.

[2] Ertegun A. (2019, 15 Aralık). İnsanoğlunun Barınma Ihtiyacı. [Çevrimiçi]. Erişim: https://slideplayer.biz.tr/slide/2290483/

[3] Türkiye Çimento Sanayicileri Birliği. (2019, 11 Kasım). Çimento Üretiminin Tarihçesi. [Çevrimiçi]. Erişim: https://www.tcma.org.tr/tr/cimento_uretiminin_tarihcesi

[4] Ertuğrul E. (2019, 17 Aralık). Mısır Piramitlerinin 20. Yüzyıl Başında Çekilmiş 9 Fotoğrafi. [Çevrimiçi]. Erişim: https://arkeofili.com/misir-piramitlerinin-20-yuzyil-basinda-cekilmis-9-fotografi/

[5] Çimen G. (2019, 17 Aralık). Dünya Çapında Görülmesi Gereken 10 Antik Yunan Tapınağı. [Çevrimiçi]. Erişim: https://arkeofili.com/dunya-capinda-gorulmesi-gereken-10-antik-yunan-tapinagi/

[6] Sim Beton. (2019, 8 Aralık). Betonun Tarihi. [Çevrimiçi]. Erişim: http://www.simbeton.com.tr/p25-betonun-zamanı

[7] O. Şimşek, Beton ve Beton Teknolojisi, Türkiye: Seçkin Yayınc1lık, 2009.

[8] Türk Plastik Sanayicileri Araştırma Geliştirme ve Eğitim Vakfi. (2019, 24 Aralık). Geri Dönüşüm. [Çevrimiçi]. Erişim: http://www.pagcev.org/geri-donusum

[9] Doğu Akdeniz Kalkınma Ajansı. (2019, 17 Aralık). Çimento Sektör Raporu 2015. [Çevrimiçi]. Erişim: https://www.dogaka.gov.tr/dokuman-merkezi/arastirma-ve-planlama/cimento-sektor-raporu$2015 /$

[10] Aslan Çimento. (2019, 20 Aralık). İlk Çimento Fabrikası. [Çevrimiçi]. Erişim: http://www.aslancimento.com.tr/tr/hakkimizda/aslan-cimento-hakkinda

[11] T. Y. Erdoğan, Beton, Türkiye: Hermes Tanıtım Ofset Bask1 Hiz. Ltd. Şti., 2013.

[12] M.S. Güner, Malzeme Bilimi - Yapı Malzemesi Beton Teknolojisi, Türkiye: Bakanlar Medya Ltd. Şti. 2012.

[13] Crc Rota. (2019, 10 Aralık). Çimento Nasıl Üretilir? [Çevrimiçi]. Erişim: http://www.crcrota.com/tr/cimento/ 
[14] T.C. Çevre Ve Şehircilik Bakanlığı. (2020, 7 Ocak). Çimento Sanayi İçin Mevcut En İyi Teknikler (Met) Ulusal Kılavuzu. [Çevrimiçi]. Erişim: https://webdosya.csb.gov.tr/db/ippc/icerikler/ulusal-met-kilavuzu-20180425132410.pdf

[15] Türkiye Çimento Sanayicileri Birliği. (2020, 7 Ocak). Türkiye Çimento Sanayicileri Birliği Hakkında. [Çevrimiçi]. Erişim: https://www.tcma.org.tr/tr/hakkimizda

[16] Türkiye Çimento Sanayicileri Birliği. (2020, 15 Ocak). Çimento Üretim Kapasitesi İstatistikleri. [Çevrimiçi]. Erişim: https://www.tcma.org.tr/tr/istatistikler/kapasite

[17] Türkiye Çimento Sanayicileri Birliği. (2020, 15 Ocak). Çimento Üretiminde Ayllk İstatistikler. [Çevrimiçi]. Erişim: https://www.tcma.org.tr/tr/istatistikler/aylik-veriler

[18] Mutegi J. (2020, 10 Şubat). Dünyanın En Büyük 10 Çimento Ş [Çevrimiçi]. Erişim: https://www.constructionkenya.com/5390/largest-cement-companies-world/

[19] Bhasin H. (2020, 10 Şubat). Dünyanın En İyi Çimento Markaları. [Çevrimiçi]. Erişim: https://www.marketing91.com/top-cement-brands-in-the-world/

[20] Garside M. (2021, 1 Nisan). 2010'dan 2020’ye Dünya Çapında Çimento Üretiminde Başlıca Ülkeler. [Çevrimiçi]. Erişim: https://www.statista.com/statistics/267364/world-cement-production-bycountry/

[21] Thomas E. (2020, 10 Şubat). 2020 Vizyonu. [Çevrimiçi]. Erişim: https://www.worldcement.com/special-reports/15012020/2020-vision/

[22] Thomas E. (2020, 10 Şubat). 2020'de Küresel Inş̧aat Piyasaları. [Çevrimiçi]. Erişim: https://www.worldcement.com/special-reports/04022020/global-data-provides-an-overview-of-globalconstruction-markets-in-2020/

[23] Anonim. (2020, 15 Şubat). Endüstri 4.0 Nedir? [Çevrimiçi]. Erişim: https://www.stendustri.com.tr/endustri-40-uygulamalari/endustri-40-nedir-h95384.html

[24] İ. Ertuğrul ve G. Deniz, "4.0 Dünyas1: Pazarlama 4.0 ve Endüstri 4.0,” Bitlis Eren Üniversitesi Sosyal Bilimler Enstitüsü Dergisi, c. 7, s. 1, ss.143-170, 2018.

[25] M.S. Imbabi, C. Carrigan ve S. McKenna, "Trends and developments in green cement and concrete technology," International Journal of Sustainable Built Environment vol. 1, no. 2, pp. 194216, 2012.

[26] Türkiye Hazır Beton Birliği. (2019, 17 Aralık). Dünyada Sektör. [Çevrimiçi]. Erişim: https://www.thbb.org/sektor/dunyada-sektor/

[27] Engin Y. (2020, 17 Aralık). Hazır Beton Üretimi ile İlgili Sıra Dışı Veriler. [Çevrimiçi]. Erişim: http://www.betonvecimento.com/beton-2/hazir-beton-veriler

[28] Anonim. (2020, 6 Ocak). Su Ayak İzi Nedir? [Çevrimiçi]. Erişim: https://www.canlibilimi.com/su-ayak-izi-nedir/

[29] Engin Y. (2020, 6 Ocak). Su Ayak İzi ve Hazır Beton. [Çevrimiçi]. Erişim: http://www.betonvecimento.com/beton-2/su-ayak-izi-ve-hazir-beton 
[30] A. Sivakrishna, A. Adesina, P.O. Awoyera ve K. Rajesh Kumar, "Green concrete: A review of recent developments," Materials Today: Proceedings vol. 27, no.1, pp. 54-58, 2020.

[31] Bozdemir M. (2019, 24 Aralık) Sürdürülebilirlik Nedir? [Çevrimiçi]. Erişim: https://www.bilgiustam.com/surdurulebilirlik-nedir/

[32] Y. Engin, M. Tarhan ve S. Kumbaracıbaşı, "Çimento Endüstrisinde Sürdürülebilir Ürerim," Beton 2013 Hazır Beton Kongresi, İstanbul, Türkiye, 2013.

[33] Anonim. (2019, 10 Aralık). Çimento Fabrikalarında Proses Fanlarının Verimliliğinin Arttırılması. [Çevrimiçi]. Erişim: https://www.elektrikport.com/teknik-kutuphane/cimento-fabrikalariproses-fanlarinda-verimliligin-artirilmasi/21267\#ad-image-0

[34] M. Schneider, "Process Technology For Efficient And Sustainable Cement Production," Cement and Concrete Research, vol. 78, pp. 14-23, 2015.

[35] Anonim. (2019, 10 Aralık). Sektörde Gelinen Son Durum. [Çevrimiçi]. Erişim: http://cementurk.com.tr/teknolojik-yenilikleri-yakindan-takip-eden-cimko-cimento-teknikoperasyonlar-direktoru-fatih-aktas-ile-2019-yili-yatirimlarini-ve-sektorde-gelinen-son-durumukonustuk/

[36] Türkiye Çimento Sanayicileri Birliği. (2019, 19 Aralık). Atık Isı Geri Kazanımı. [Çevrimiçi]. Erişim: https://www.tcma.org.tr/tr/atik_isi_gerikazanimi

[37] M. E. Alpan, "Çimento Sektöründe Atık Isı Geri Kazanımı Sistemleri Kullanımı,” 3. Sanayi Şurası, Ankara, Türkiye, 2013.

[38] Y. Koçak, "Tras İkame Oranının Portland Çimentosunun Fiziksel Ve Mekanik Özelliklerine Etkisi," Engineering Sciences, vol. 5, no. 3, pp. 564-572, 2010.

[39] M. Karimaei, F. Dabbaghi, A. Sadeghi-Nik ve M. Dehestani, "Mechanical performance of green concrete produced with untreated coal waste aggregates," Construction and Building Materials, vol. 233, pp. 1-12, 2019.

[40] O. Sallı Bideci, K. Mercanoğlu ve A. Bideci , "Öğütülmüş Cam Elyaf Takviyeli Beton (Grc) Atıklarının Çimento İkame Malzemesi Olarak Kullanılabilirliği", Selçuk Üniversitesi Mühendislik, Bilim Ve Teknoloji Dergisi, c. 6, s. 2, ss. 198-206, 2018.

[41] L. Tostia, A. Zomeren, J. R. Pelsb ve R.N.J. Comansa, "Technical and environmental performance of lower carbon footprint cement mortars containing biomass fly ash as a secondary cementitious material," Resources, Conservation \& Recycling vol. 134, pp. 25-33, 2018.

[42] Anonim. (2020, 15 Ocak). Fabrikalarda Rüzgar Enerjisi. [Çevrimiçi]. Erişim: http://bestdergisi.com.tr/bolumler/dosya/ruzgar-tribunuyle-kendi-enerjisini-ureten-fabrika/

[43] Anonim. (2020, 15 Ocak). Fabrikalarda Rüzgar Enerjisi. [Çevrimiçi]. Erişim: https://www.aa.com.tr/tr/ekonomi/ilk-ruzgar-turbini-fabrikasi-kasim-sonunda-devreyegirecek/1636954

[44] Anonim. (2020, 15 Ocak). Fabrikalarda Rüzgar Enerjisi. [Çevrimiçi]. Erişim: https://ticaret.gov.tr/blog/sektor-haberleri/siemens-gamesa-yakinda-turkiyedeki-fabrikasinda-ruzgarturbini-motor-besigi-uret 
[45] Arçelik A.Ş. (2020, 15 Ocak). Enerji Verimliliği. [Çevrimiçi]. Erişim: http://www.arcelikas.com/sayfa/209/Arcelik_te_Enerji_Verimliligi

[46] Anonim. (2020, 15 Ocak). Fabrikalarda Rüzgar Enerjisi. [Çevrimiçi]. Erişim: https://www.borsatek.com/akcansaya-ruzgar-enerjisi-6459h.htm

[47] Tabakoğlu S. (2020, 15 Ocak). Fabrikalarda Güneş Enerjisi. [Çevrimiçi]. Erişim: https://www.yenienerji.com/adana-cimento-gunes-enerjisi-santrali

[48] Anonim. (2020, 15 Ocak). Fabrikalarda Güneş Enerjisi. [Çevrimiçi]. Erişim: https://www.enerjiatlasi.com/gunes/adana-cimento-gunes-enerji-santrali.html

[49] Anonim. (2020, 15 Ocak). Fabrikalarda Güneş Enerjisi. [Çevrimiçi]. Erişim: https://www.haberler.com/mersin-fabrika-elektrigini-gunes-enerjisinden-6885143-haberi/

[50] TÜIK. (2020, 10 Ocak). Net Elektrik Tüketiminin Sektörlere Göre Dağılımı. [Çevrimiçi]. Erişim:https://data.tuik.gov.tr/Search/Search?text=Net\%20Elektrik\%20T\%C3\%BCketiminin\%20Sekt \%C3\%B6rlere\%20G\%C3\%B6re\%20Da\%C4\%9F\%C4\%B11\%C4\%B1m\%C4\%B1

[51] V. Vishwakarma ve D. Ramachandran, "Green Concrete mix using solid waste and nanoparticles as alternatives - A review," Construction and Building Materials, vol. 162, pp. 96-103, 2018.

[52] J. G. Jang, G. M. Kim, H. J. Kim ve H.K. Lee, "Review on recent advances in CO2 utilization and sequestration technologies in cement-based materials," Construction and Building Materials, vol. 127, pp. 762-763, 2016.

[53] V. M. John, M. Quattrone, P.C.R.A. Abrão ve F.A Cardoso, "Rethinking cement standards: Opportunities for a better future," Cement and Concrete Research, vol. 124, pp. 1-18, 2019.

[54] W Schmidt, M. Alexander ve V. John, "Education For Sustainable Use of Cement Based Materials," Cement and Concrete Research, vol. 114, pp. 103-114, 2017.

[55] Ş. Ordu ve E. Öztürk, "Çimento Fabrikalarında Alternatif Hammadde ve Yakıt Kullanımı: Örnek Çalışma," Artvin Çoruh Üniversitesi Doğal Afetler ve Çevre Dergisi, c. 3, s. 2, ss. 87-92, 2017.

[56] Özdemir A. (2019, 24 Aralık). Geri Dönüşüm ve İnşaat Sektöründeki Yeri. [Çevrimiçi]. Erişim: https://www.aykutozdemir.com.tr/insaat/geri-donusum-ve-insaat-sektorundeki-yeri.html

[57] Ares Çimento. (2020, 7 Ocak). Geri Dönüşüm. [Çevrimiçi]. Erişim:

https://www.arescimento.com.tr/geri-donusum/ 